\title{
RAFAŁ CZEKALSKI
}

Papieski Wydział Teologiczny w Warszawie

\section{Marcusa Vogta próba integracji zasad ekorozwoju z Katolicką Nauką Społeczną}

Słowa kluczowe: ekorozwój, Katolicka Nauka Społeczna, kryzys ekologiczny Key words: eco-development, catholic social teaching, ecological crisis

\section{SUMMARY}

\section{Marcus Vogt's attempt at integrating the principles of eco-development with the Catholic Social Teaching}

In this article I have attempted to answer the question of the possibilities of integrating the principles of eco-development with Catholic social teaching. I have done so on the basis of the works of a German moral theologian M. Vogt. The integration of the principles of eco-development with the Catholic social teaching may take place in a dialogue between the theology of creation together with its implications and the knowledge of nature. Considering the issue from the socioethical perspective it is vital to work out a new social agreement, which would take into account justified, although unspecified, claims of future generations. The integration of the principles of eco-development with Catholic social teaching is by no means impossible, although Vogt warns against treating the concept of eco-development as a superior issue - it is not a solution itself, but rather a key to the solution of contemporary problems at an intersection of three dimensions: social, economic and ecological. The proposed principle of eco-development shall become autonomous not in isolation to the traditional principles 
of Catholic social teaching, but in relation to them. The novelty of this principle is more about a new perspective, where man has to learn to see himself as part of creation as a whole. The principle also calls for a new way of thinking, which is the transition from a linear to a network way of thinking.

\section{Wstęp}

Celem niniejszego artykuły jest przedstawienie próby integracji zasad ekorozwoju z katolicką nauką społeczną, jakiej podjął się M. Vogt. Podstawą niniejszego artykułu jest praca habilitacyjna prof. M. Vogta przedłożona na Uniwersytecie Ludwiga Maximiliana w Monachium: Prinzip Nachhaltigkeit. Ein Entwurf aus theologisch-ethischer Perspektive (Zasada rozwoju zrównoważonego. Projekt z teologiczno-etycznej perspektywy $)^{2}$. Markus Vogt, jako teolog moralista, podejmuje ten temat z perspektywy chrześcijańskiej wiary, której stałym elementem jest odpowiedź na znaki czasu (signum temporis). Dla Autora głównym celem stało się ukazanie etycznego profilu zasady ekorozwoju. Dokonuje tego na dwóch drogach. Po pierwsze na drodze dialogu pomiędzy teologią stworzenia a wiedzą przyrodniczą, po drugie, wychodząc z perspektywy teorii sprawiedliwości. Jeśli idzie o tę drugą drogę Vogt analizuje konflikt, jaki zachodzi pomiędzy generacjami i próbuje wykoncypować kryteria nowej, przyszłościowej umowy społecznej.

Struktura artykułu jest następująca. W pierwszym punkcie przybliżymy bardzo ogólnie, na czym polega zasada ekorozwoju, jakie inne terminy stosuje się do jej określenia, przypomnimy także genezę powstania tej zasady. W drugim punkcie w oparciu o tekst M. Vogta będziemy poszukiwali odpowiedzi na pytanie, jakie jest zadanie kościoła w odniesieniu do problemów współczesności. Z teologii wiemy, że wiąże się ono z potrójną funkcją wiary: krytyczną, motywacyjną i integra-

1 M. Vogt jest jednocześnie członkiem grupy zajmującej się problemami ekologicznymi niemieckiej Konferencji Episkopatu (DBK) oraz różnych grup doradztwa politycznego.

2 Wydana przez eokom: Monachium 2009. 
cyjną. W trzecim punkcie przedstawimy odpowiedź Vogta na pytanie: jaka etyka dla ekorozwoju. Czwarty punkt ukaże w sposób schematyczny wszystkie problemy wokół koncepcji (zasady) ekorozwoju. Punkt piąty ma charakter podsumowujący i ukazuje możliwość integracji zasad ekorozwoju z zasadami katolickiej nauki społecznej.

\section{Czym jest i jak powstała zasada ekorozwoju?}

Jako fachowy termin sustainable (coś trwałego, oddziaływującego) jest obecny w leśnictwie, w jęz. angielskim, od roku $1713^{3}$. W połowie $\mathrm{XX}$ wieku, w obliczu kryzysu ekologicznego termin ten znalazł szersze zastosowanie i odnosi się do rozwoju, który obejmuje w sobie także wymiar ekologiczny. Znalazło to odzwierciedlenie w licznych dokumentach Narodów Zjednoczonych dotyczących ochrony środowiska, rozwoju, demografii, przyszłości, ekonomii światowej. Wśród tych dokumentów należy wymienić: Światowa strategię ochrony przyrody (1980), Światowa Karte Przyrody (1982). Światową popularność termin ten zdobył na szczycie ziemi w Rio de Janeiro, w roku 1992. W języku polskim stosuje się bardzo różne określenia: ekorozwój, rozwój zrównoważony i trwały, rozwój samopodtrzymujący, zbalansowany. Zasada ta jest próbą odpowiedzi na postępującą degradację środowiska naturalnego, które stanowi podstawę egzystencji człowieka. Degradacja ta nasiliła się w okresie rywalizacji międzysystemowej po Drugiej Wojnie Światowej. W okresie tym na skutek nadmiernej i krótkowzrocznej eksploatacji doszło do wyginięcia wielu gatunków flory i fauny co doprowadziło do zmniejszenia różnorodności populacyjnej i stratę niepowtarzalnego układu genetycznego oraz osłabienie stabilności całych ekosystemów. Aby temu przeciwdziałać społeczność międzynarodowa podjęła wielki wysiłek w celu określenia odpowiednich standardów moralnych mających za cel ochronę dóbr naturalnych, będących podstawą egzystencji

Niektórzy wiążą genezę tego terminu z leśnictwem niemieckim i z Hansem Carlem von Carlowitzem, według którego zrównoważona gospodarka lasami miała polegać na tym, aby wycinać tyle drzewa, ile może w to miejsce urosnąć. 
całej ludzkości. Pierwsza międzynarodowa konferencja poświęcona problemom środowiska naturalnego odbyła się w Sztokholmie w roku 1972. Następne odbyły się kolejno w Rio de Janeiro (1992)4, Kioto (1997), Johannesburgu (2002), Konferencja FAO w Rzymie (1997). Konferencje te nie zawsze spełniały pokładane $\mathrm{w}$ nich nadzieje, na przeszkodzie stały polityczne podziały, rozbieżności interesów ekonomicznych i nacjonalizm.

Do istotnych dokumentów organów międzynarodowych, oprócz wyżej wspomnianych, należy wymienić: Jednolity Akt Europejski (Single European Act) z 1987, Traktat Rzymski o Europejskiej Wspólnocie Gospodarczej z 1977r., Traktat o Unii Europejskiej z 1991 r. (Maastricht) oraz Traktat Amsterdamski (1997r.). Traktat Rzymski w art. 25, określając cele Unii Europejskiej w dziedzinie ochrony środowiska, wymienia: zachowanie, ochronę i poprawę jakości środowiska przyrodniczego, ochronę zdrowia i życia ludzkiego oraz racjonalną eksploatację zasobów przyrodniczych, zwłaszcza nieodnawialnych.

Kwestia ekologiczna nieodłącznie związana jest z kwestią demograficzną. Tej problematyce poświęcone zostały Światowe Konferencje Ludnościowe ONZ w Bukareszcie w 1974 r., w Meksyku w 1984, a także konferencja $w$ sprawie środowiska naturalnego i rozwoju w Rio de Janeiro w $1992^{5}$. Na konferencjach tych zwrócono również uwagę

4 Na konferencji tej przyjęto trzy dokumenty: Deklarację z Rio, Agendę 21 i Deklarację o Ochronie Lasów. W Agendzie położono nacisk na wychowanie do ochrony środowiska. Jest to obowiązek uniwersalny i spoczywa na barkach międzynarodowych organizacji rządowych i pozarządowych. W części czwartej Agendy wskazano na duże znaczenie technologii stosowanej w ochronie środowiska oraz potrzebę dzielenie się tymi technologiami z krajami biednymi. W rozdziale $\mathrm{V}$ Agendy zwrócono szczególną uwagę na problemy demograficzne.

5 Konferencja ta miała na celu dookreślenie idei zrównoważonego rozwoju. Uchwalono tam rezolucję, zwaną z powodów formalnych Agendą 21, która została przyjęta i podpisana przez większość uczestników obrad. Zawarto w niej globalny proekologiczny program działań na rzecz jakości życia człowieka, także przyszłych pokoleń. W rezolucji tej akcenty padały na przeciwdziałanie kryzysowi ekologicznemu, powstałemu w dużej mierze w wyniku globalizacji ekonomicznej, ale i z całą mocą podkreślono za Deklaracją z Rio, że to „istoty ludzkie są w centrum zainteresowania w procesie zrównoważonego rozwoju" (Deklaracja z Rio (1992, zasada 1). 
na edukacje ekologiczną. Prawdziwą przyczyną niedorozwoju niektórych regionów jest brak właściwej edukacji, która przyczyniłaby się do zwiększenia świadomości ekologicznej, ale także do samodzielności mieszkańców tych regionów. Aby przeciwdziałać temu opóźnieniu cywilizacyjnemu niektórych regionów świata w siedzibie ONZ w 2005 ogłoszono Dekadę Edukacji na temat Zrównoważonego Rozwoju (20052014), której głównym celem jest edukacyjne upowszechnienie idei zrównoważonego rozwoju społecznego, ekonomicznego i ekologicznego, jako istotnego elementu działań wdrażających nową, globalną strategię rozwoju człowieka. Strategia ta zrywa z dotychczasową opartą na liberalizmie filozofią społeczną. Nowa filozofia zrównoważonego rozwoju biorąca pod uwagę sytuację kryzysową oraz odpowiedzialność za przyszłe pokolenia wyznacza nowe standardy etyczne, których przestrzeganie jest gwarancją zrównoważonego życia. Wprowadzanie więc konkretnych zmian nie może się obejść bez refleksji aksjologicznej, która wydobywa z katalogu wartości te, które najlepiej służą integralnemu rozwojowi człowieka (ludzkości).

Z odpowiedzialności za rozwój świata, środowisko naturalne, przyszłość ludzkości, nie jest zwolniony Kościół Katolicki. Przeciwnie, jako najstarszy Global Player jest on wezwany do uczestniczenia w procesie kształtowania się nowej społecznej rzeczywistości. Podstawą tej odpowiedzialności jest wiara, która zawiera w sobie trzy - wspomniane już wyżej - funkcje: krytykującą, integrującą i motywującą. W następnym punkcie przyjrzymy się oryginalnym kompetencjom Kościoła w dziedzinie społecznej i ekologicznej.

\section{Zadanie Kościoła Katolickiego wobec problemów współczesności}

Na czym dokładnie polega mandat kościoła katolickiego i jego etyczna kompetencja? M. Vogt stara się wskazać wyraźne granice ingerencji Kościoła. Granicę tę wyznacza pluralizm jako konsekwencja, granica i wyzwanie moralności chrześcijańskiej. W tym publicznym dyskursie Kościół występuje jako jeden z wielu jego uczestników, nie tylko, jako 
pouczający, ale i także jako uczący się. Opisując zadania, przed jakimi stoi teologia katolicka, M. Vogt korzysta z doświadczenia etyki autonomicznej, która już wcześniej wyraziła je w słynnym trójmianie: krytykować, motywować, integrować. ${ }^{6}$ Te trzy obszary zadań zostaną teraz bliżej przedstawione:

\section{a. funkcja krytyczna}

Moralność - pisze Vogt - jest zawsze niewygodna i wiąże się z ograniczeniami. W niej zawsze znajduje się pewien element krytyki. W sposób szczególny znalazła ona swój wyraz w krytyce społecznej, która niestety bardzo często przyjmowała postać rewolucji i anarchii. Współcześnie krytyka ta wyraża się chociażby w postaci ruchów alterglobalistów, którzy sprzeciwiają się niesprawiedliwości w świecie, braku transparencji, i neokolonializmowi. W szeregu tych „niezadowolonych” bardzo często stają radykalne ruchy ekologiczne, nie cofające się nawet przed eko-terroryzmem. Wydaje się, że koncepcja ekorozwoju stanowi naukową formę protestu przeciwko dotychczasowemu rozumieniu rozwoju. Koncepcja ekorozwoju celuje w nowy kontrakt społeczny, który wymaga od społeczeństwa przeorientowań i zmiany stylu życia (Por. Vogt 2009: 113n.). Vogt zwraca uwagę na konieczność kontynuacji krytyki społecznej, i nie chodzi w tym przypadku o jakiekolwiek działania wywrotowe, czy anarchiczne. Celem tej krytyki jest ciągłe podtrzymywanie ideałów i wartości, które wiążą się z koncepcją ekorozwoju. Bardzo często mamy do czynienia z fasadowością działań rządowych czy międzypaństwowych, które zmieniają jedynie retorykę, wymieniają kilka pojęć, a w rzeczywistości realizują stare i najczęściej krótkowzroczne programy. Dlatego bardzo istotną rolę może wypełnić etyka teologiczna, która nie daje się zamknąć w utopiach bezgranicznego postępu. Etyka chrześcijańska wskazuje granice, tego co możliwe

6 Twórcą etyki autonomicznej jest A. Auer, który oprócz zagadnień fundamentalno-etycznych jako jeden z pierwszych teologów niemieckich podjął temat etyki ekologicznej. Zob. tenże, Umweltethik. Ein theologischer Beitrag zur ökologischen Diskussion, Patmos Verlag Düsseldorf 1984. 
i wskazuje w ten sposób ideologie, które w imię rzekomego „większego dobra" zniewalają człowieka wprowadzają niesprawiedliwe układy.

\section{b. funkcja motywacyjna}

Drugą funkcją etyki teologicznej jest motywacja. Wiemy z praktyki życia, że człowiek, szczególnie wobec zadań trudnych i długotrwałych, potrzebuje motywacji. Dlatego zadaniem etyki jest motywować, ukazywać dobro (ideał), który jest podany do realizacji, oraz, niekiedy od strony negatywnej winna ona ukazywać skutki zaniechania, nie-realizacji dobra. Problemem współczesnej etyki - podkreśla Vogt - nie jest uzasadnienie działań czy celów, ale ukazanie ich w takim świetle, aby były one do przyjęcia i były atrakcyjne ${ }^{7}$. Vogt, który bardzo wiele zrobił dla edukacji ekologicznej, znane są jego wystąpienia na różnych sympozjach i zjazdach, a także publikacje dotyczące tej tematyki, jest zdania, że wychowanie stanowi współcześnie najważniejsze pole działania etyki. Wiemy z historii etyki, że nie zawsze tak było. Skarżył się na to między innymi nestor polskiej etyki wychowawczej o. J. Woroniecki. Oczywiście, nie wystarczy motywacja poszczególnych osób, potrzeba jeszcze odpowiednich ram instytucjonalnych, które będą zachęcały do wcielania konkretnych programów pro-ekologicznych w życie. Vogt ze smutkiem zauważa, że dotychczas dominował dyskurs przyrodniczo-filozoficzny, który istniał w oderwaniu od dyskursu społeczno-teoretycznego i ekonomicznego. Także w dziedzinie motywacji nieocenioną rolę ma do odegrania duchowość chrześcijańska, która pozwala na odkrycie wymiaru duchowego człowieka. Człowiek żyje w konkretnych układach społecznych, ale pomimo tego transcenduje on te układy i jest stałym punktem odniesienia wszelkich działań społecznych. Chodzi w tym przypadku o wytworzenie nowej tożsamości, a - jak wiado-

7 „Umweltschutz und globale Gerechtigkeit sind nicht primär ein Problem rationaler Begründung, sondern oft eine Frage de Willensbildung auf einer tieferen, emotionalen und identitätsbildenden Ebene“ (Vogt 2009: 486). Vogt powołuje się w tym miejscu na publikację Christopha Baumgartnera, w której mowa jest o post-normatywnej fazie etyki, w której coraz mniejszą rolę będą odgrywały uzasadnienia (Definition von Normen), a coraz większą motywacja (Baumgartner 2005). 
mo - nie ma tożsamości bez wartości. To wartości nadają „farbę” życiu ludzkiemu i właśnie w tej wartościowo-twórczej, a przez to tożsamościowo-twórczej roli występuje wiara w stworzenie, która w ten sposób przyczynić się może do wytworzenia postaw proekologicznych (Por. Baumgatner 2005: 270-283, 308-319).

Wydaje się, że to nowe duchowe podejście do etyki w obliczu doświadczanych współcześnie granic racjonalizmu staje się koniecznością. Warto także odkryć „racjonalność ukrytą”, tkwiącą w zwyczajach ludzkich i obyczajach. Vogt zauważa, że czasami jest tam więcej rozumu (racjonalności) niż w teoretycznych i wydedukowanych normach, które grzeszą abstrakcyjnością i niepraktycznością. Teolog monachijski zwraca uwagę na jeszcze jedną niekiedy umykającą uwadze sprawę, mianowicie na to, że norma staje się jedynie wtedy skuteczna, kiedy staje się zwyczajem, nawykiem (Vogt 2009: 100). Etyka chrześcijańska nie powinna zatem koncentrować się jedynie na uzasadnieniach, w których z reguły i tak posługuje się konstrukcjami stricte filozoficznymi, ale powinna odkryć (dla innych) to bogactwo tradycji, tzw. „etos wcielony” (gelebte Ethos), który stanowi formę przetłumaczenia wymagań etyki (Tamże: 101). To nowe podejście do natury (świata stworzonego) winna cechować „nieinstrumentalność, a to wydaje się właśnie największym etycznym problemem. Natura nigdy nie powinna być postrzegana jedynie jako materiał do wytworzenia produktu. Trzeba odkryć na nowo perspektywę, która obejmować będzie nie tylko to, co faktyczne i mierzalne, ale odkryje także piękno natury, jej sens, symboliczność, misteryjność. Dlatego działanie Kościoła nie może być zorientowane jedynie na praktyczno-ekologiczną albo polityczną działalność, ale winno być pojmowane jako duszpasterstwo mistagogiczne, które będzie dawało duchową orientację. W przeciwnym razie działalność ekologiczna Kościoła pozostanie jedynie fenomenem granicznym. To ze środka wiary ma płynąć działanie proekologiczne Kościoła, który winien wykorzystać swoją pozycję i obecność w społeczeństwie do formowania ludzi w kierunku nowej ekologicznej i społecznej duchowości ${ }^{8}$.

8 Wspomniał o tej nowej duchowości i konieczności zmiany mentalności także Benedykt XVI w swoim Orędziu na ŚDP w 2010, w punkcie 14 czytamy: „Chrześcija- 


\section{c. funkcja integracyjna}

Trzecią funkcją teologii jest integracja. W przypadku zasady ekorozwoju mamy do czynienia z wieloma grupami interesów, grupami nacisków, aktorów życia społecznego. Integracja zatem stanowi warunek skutecznego działania, u podstaw którego musi być gotowość dialogu. Celem tak rozumianej integracji nie jest jednolitość, ale zdolność działania. Vogt odwołuje się do treści dokumentu Agenda 21 (rozdz. 23-32), w którym nie chodzi o narzucenie jednolitych zamiarów, ale o wzmocnienie roli ważnych grup społecznych. Koncepcja ekorozwoju zbieżna jest zatem z zasadą subsydiarności. Chodzi tu zatem o jedność w różnorodności (Por. Vogt 2009: 102). Rodzi to jednak nowe problemy, które bardzo trafnie wspomniany Autor wychwycił. Chodzi mianowicie o operacjonalizację norm, czyli o konkretne i zobowiązujące normy na płaszczyźnie wprowadzania idei ekorozwoju. Na tej płaszczyźnie porozumienia nie ma. Mało tego dochodzi tu do dużych różnic. Trudno jest bowiem znaleźć konkretne nomy, które obowiązywałyby wszystkie państwa i były przez nie akceptowalne. Nikt nie ukrywa, że potrzeba wspólnego działania, wykształcenia nowych postaw, oszczędności w stosowaniu surowców nieodnawialnych, poszukiwania nowych (ekologicznych) technologii. Kiedy jednak idzie o ograniczenia, konkretne działania, które jako skutek negatywny mają chociażby spowolnienie wzrostu gospodarczego czy też niezadowolenie społeczne, żaden rząd nie godzi się na takie rozwiązania. Dominuje zatem podejście krótkowzroczne. Potrzeba zatem nowej świadomości, której kreatorami mogą być niesformalizowane grupy NGOs, wywierające nacisk na niezdecydowane lub pasywne rządy. Oczywiście ekologii nie można ideologizować, czynić z niej nowej religii, a niekiedy spotyka się i takie podejście. Postawa proekologiczna jest obowiązkiem współczesnego człowieka, który musi zadbać także o istnienie nie gorszych warunków

nie, oświeceni przez Boże Objawienie i wierni Tradycji Kościoła, chcą wnieść swój wkład. Postrzegają oni wszechświat i jego wspaniałość w świetle stwórczego dzieła Ojca i odkupieńczego dzieła Chrystusa, który przez swoją śmierć i zmartwychwstanie pojednał z Bogiem «i to, co na ziemi, i to, co w niebiosach» $(K o l$ 1, 20)”. 
dla przyszłych pokoleń. Wielu autorów domaga się zatem ustanowienia odpowiednich procedur postępowania dla procesu integracyjnego, na przykład przez instytucjonalne wzmocnienie programów ochrony środowiska Narodów Zjednoczonych, którym dotychczas brakuje narzędzi sankcjonowania tych, którzy nie respektują wspólnych strategiczno-rozwojowych ustaleń. Chodzi zatem o stworzenie etyki ekorozwoju, która byłaby zdolna oddziaływać politycznie.

\section{Jaka etyka ekorozwoju?}

Jak zatem winna taka etyka ekorozwoju wyglądać? Vogt precyzuje, że taka koncepcja winna być jednocześnie otwarta, ale i zobowiązująca, powinna być także podporządkowana logice współdziałania (interakcji) heterogenicznych elementów, takich jak: ekonomia, ekologia, etyka społeczna i w ten sposób otwierać nowe perspektywy, nie poddając się jednocześnie logice dowolności. W koncepcji tej ogranicza się etykę normatywną, a koncentruje się na ukazaniu nowych możliwości. ${ }^{9}$ Istotną rzeczą jest również utrzymanie balansu pomiędzy wspomnianymi trzema funkcjami etyki teologicznej: krytykującej, motywującej, integrującej. Kluczem interpretacyjnym w zaproponowanym przez Vogta modelu jest zasada „sieciowości” (retinity), która odzwierciedla skomplikowaną strukturę problemów, które trzeba rozważać jednocześnie. Niebezpieczeństwem, które tenże teolog dostrzega, jest zagubienie się w ilości tematów, które nakładają się na siebie. Dlatego też Vogt stara się być wierny teologicznej perspektywie (teologia znaków czasu), która stanowi kryterium do wyboru tematów, a głównymi celami są odnalezienie sensów (Sinnfragen) oraz precyzacja wymagań sprawiedliwości. Jednocześnie Vogt zwraca uwagę na receptywną, sekundarną kompetencję teologa, który korzysta z owoców pracy innych specjali-

9 Vogt opowiada się za etyką integrującą, którą zasadniczo cechuje metoda (nieskończonego) moralno-uzasadniającego i dyskursywnego poszukiwania rozwiązań: „Integrative Ethik ist eine Methodik der begründeten und diskursiven Entscheidungsfindung, in einem prinzipiell nich abschliessbaren Abwägungs- und Lernprozess“ (Vogt 2009: 103). 
stów. Vogt nie jest zwolennikiem tak zwanej etyki odpowiedzialności, która we współczesnej wersji, skupia się na rozważaniu skutków działania, i wykazuje niewydolność w formułowaniu zasad. Autor zauważa, że we współczesnym, coraz bardziej kompleksowym i interaktywnym świecie, dokładne obliczenie skutków działania jest coraz trudniejsze. O wiele bardziej pomocne w konstruowaniu etyki ekorozwoju jest pojęcie sprawiedliwości, która zarówno przestrzennie, globalnie i czasowo, jako między-generacyjna sprawiedliwość, a przez to jako etyka przyszłości, lepiej, choć cały czas niedostatecznie, rozwiązuje kompleksowe problemy moralne współczesnego świata. Kompleksowość rodzi jednak coraz to nowe wyzwania metodologiczne. Vogt zwraca uwage też na to, że dotychczasowy model egalitarystycznie pojmowanej sprawiedliwości nie sprawdza się w odniesieniu do globalnego podziału zasobów i w odniesieniu do momentu przyszłościowego. Nowe pytania, przed którymi staje świat, takie jak: czy wszyscy posiadają takie same prawo do dostępnych resursów? czy potrzebujemy rządu światowego (global governance) jako instytucjonalnego warunku globalnej sprawiedliwości, domagają się nowych odpowiedzi i nowego myślenia. Autor, w oparciu o dokumenty organizacji międzynarodowej, przedstawia priorytety dla politycznego działania. Są to: obniżenie ubóstwa o połowę (do 2015), konieczność instytucjonalnej światowej reformy celującej w eko-społeczną gospodarkę wolnorynkową; konieczność zmian w sektorze energii, wyżywienie świata przez zrównoważone i globalne rolnictwo, ochrona biologicznej różnorodności.

\section{Problemy z koncepcją ekorozwoju}

M. Vogt ma świadomość, że jesteśmy na początku drogi, jeśli idzie o precyzację pojęcia i wymagań etycznych związanych z koncepcją (zasadą) ekorozwoju. Autor ten, ale nie tylko on, uważa, że koncepcja ekorozwoju jeszcze długo będzie pozostawała jedynie punktem wyjścia krytyki, w celu znalezienia nowej miary i kryterium postępu, który obejmowałby w sposób zrównoważony trzy podstawowe wymiary: 
społeczny, ekonomiczny i ekologiczny. Dotychczas koncepcja zrównoważonego rozwoju, pomimo różnych państwowych strategii i programów, pozostaje nie zobowiązującą pustą formułą, która domaga się pogłębienia $\mathrm{w}$ odniesieniu do centralnych strategicznych problemów, którym ma zaradzić. Marcus Vogt przedstawia następujące problemy kluczowe, które rodzą się przy bliższym przyjrzeniu się koncepcji ekorozwoju. Są to:

a) Jaka relacja winna zachodzić pomiędzy substytucją kapitału naturalnego a technicznymi innowacjami? Jak rozumieć pojęcie natury? Pytania te wiążą się z dyskusją wokół koncepcji ekorozwoju (słabej i mocnej);

b) Problem społecznego wymiaru koncepcji ekorozwoju. W jakiej relacji do siebie pozostaje walka $\mathrm{z}$ ubóstwem i zachowanie naturalnego środowiska. Niekiedy są to cele się wykluczające, albo i zwalczające;

c) W jakiej relacji pozostają wspomniane trzy wymiary, bo nie chodzi tu wbrew pozorom o takie same traktowanie, ale o politykę wielowymiarową (Querschnitspolitik) i sieciowość, które wyznaczają konkretne cele strategiczne. Zakłada to pewną hierarchię wartości, której podporządkowane są te trzy wymiary;

d) Refleksji musi zostać podany również nowy model dobrobytu, który występuje pod nazwą ekonomia ekologiczna;

e) Przedmiotem troski pozostaje również wzajemna relacja jaka zachodzi pomiędzy energią, pracą i kapitałem;

f) Należy poddać krytyce „fetysz wzrostu gospodarczego” oraz podjąć próbę odnalezienia nowych miar dla postępu;

g) Próba znalezienia nowych dróg społecznej partycypacji w otwartym procesie poszukiwania jako procesie pogłębiania zrozumienia pojęć w polityczno-teoretycznej perspektywie. (Por. Tamże)

Nie ulega jednak wątpliwości, że współcześnie koncepcja ekorozwoju pozostaje jedynie pewną wzniosłą ideą. Vogt cytuje niemieckich autorów, którzy koncepcję ekorozwoju nazywają: Leitbild, Alleskleber, intelektuellen Mix, Containerbegriff, semantische Chamäleon, których 
istotną cechą jest nieostrość. Dlatego też dla Vogta pojęcie ekorozwoju jest ambiwalentne i wymaga intelektualnych rozróżnień.

\section{Zasada ekorozwoju jako chrześcijańska zasada społeczna?}

Niewątpliwie jest to śmiałe przedsięwzięcie etyczne, które znajduje swoje uzasadnienie w samej orientacji katolickiej nauki społecznej na rozwiązywanie nowych problemów, które pojawiają się z biegiem upływu czasu (teologia znaków czasu), jak i też w pewnego rodzaju synchronii, jaka panuje pomiędzy innymi zasadami katolickiej nauki społecznej, w szczególności personalizmu, solidarności i subsydiarności, i zasadą ekorozwoju (Por. Tamże: 459). Postulowana zasada ekorozwoju uzyskuje swoją niezależność (samodzielność) nie w izolacji do innych społecznych zasad, ale właśnie w relacji do nich. Problem odniesienia człowieka do natury pozwala - zdaniem Vogta - na nowo odczytać, pogłębić wspomniane trzy zasady społeczne: personalizmu, solidarności i subsydiarności (Tamże, s. 469). Zasada ta nie stanowi zatem jedynie dodania nowego przedmiotu badań (poszerzenia zakresu), ani też nowego sposobu uzasadniania. Nowość tej zasady polega na nowym horyzoncie, człowiek bowiem musi nauczyć się widzieć siebie jako część całego stworzenia, a swoją wolność i społeczny rozwój rozumieć nie, jak to bywało wcześniej, jako emancypację z kajdan natury. Dlatego też Vogt postuluje ekologiczną etykę społeczną, która problemy społeczne i międzyludzkie dociekać będzie łącznie z ekologicznymi. Problemy, które występują na przecięciu tych płaszczyzn, rozwiąże się wspólnie albo w ogóle. Vogt cytuje w tym miejscu Wofganga Sachsa: „Nie ma sprawiedliwości bez ekologii. Nie ma ekologii (chodzi tu o ekologiczną stabilizację) bez sprawiedliwości“"10.

Dlatego też monachijski teolog domaga się jakościowego rozszerzenia zasad społecznych (Por. Tamże: 476nn). W ten sposób sama koncepcja ekorozwoju zdobywa ważne treści do uzasadnienia, etyczną siłę

10 „Keine Gerechtigkeit ohne Ökologie. Keine Ökologie (gemeint ist ökologische Stabilisierung) ohne Gerechtigkeit” (Tamże, Por. Sachs 2003: 22). 
motywującą a także postać organizacyjną wypływająca z bliskości do znanych już zasad społecznych ${ }^{11}$. Bez wspomnianych trzech zasad zasada ekorozwoju mogłaby:

- po pierwsze: skończyć w naturalistycznych koncepcjach (przed tym chroni z. personalistyczna);

- po drugie: bez z. solidarności utonąć w organizacyjnej pustej przestrzeni społecznej;

- po trzecie: bez uznania zasady subsydiarności, zaangażowania mniejszych jednostek społecznych, brakowałoby jej organizacyjnego serca (Organisatorische Herzstück). Groziłaby wtedy nad-organizacja, biurokracja, reglamentacja, centralizacja, ubezwłasnowolnienie itp. Zabrakłoby struktur wolności i dopasowania do lokalnych społeczno-kulturowych i naturalnych przestrzeni życiowych ${ }^{12}$.

Vogt podkreśla samodzielność ekologicznego wymiaru wyżej wymienionych zasad. Ekologiczny wymiar nie może zostać sprowadzony jedynie do momentu interpretacyjnego społecznej i ekonomicznej odpowiedzialności, lecz musi osiągnąć swoją własną, autonomiczną doniosłość (Por. Tamże: 476). Ekologiczna etyka zbudowana na zasadzie ekorozwoju nie wyprowadza etyki z teorii społeczeństwa i etyki społecznej, przeciwnie jeszcze głębiej w nią wprowadza. Społeczne i ekologiczne problemy nie powinny być rozważane w sposób niezależny, ale w interdyscyplinarnej, sieciowej perspektywie. Publikacje tak znanych etyków i przedstawicieli katolickiej nauki społecznych jak: M. Vogt, H.J. Münk, H. Wulsdorf ${ }^{13}$, są świadectwem tego, że Kościół

11 „So gewinnt das Nachaltigkeitsprinzip wichtige Inhalte seiner Begründung, seiner ethischen Motivationskraft und seiner organisatorischen Gestalt aus dem engen Verweisungszusammenhang zu den bekannten Sozialprinzipien“ (Tamże, s. 476).

12 Należy na marginesie zauważyć, że papież Benedykt XVI bardzo poważnie potraktował zasadę ekorozwoju. W swojej ostatniej encyklice Caritas in veritate poświęcił jej aż trzy punkty (48-51).

13 Wymienię tylko kilka znaczących pozycji wyżej wymionionych autorów: H.J. Münk, Nachhaltige Entwicklung und Soziallehre, StZ 216 (1998) z.4, s. 231-245; Tenże, Retinität als neues Sozialprinzip, w: Auf neue Art Kirche sein. WirklichkeitenHerausforderungen-Wandlungen. Festschrift für Bischof Dr. Josef Homeyer, red.: W Schreer, G. Steins, München 1990, s. 540-549; M. Vogt, Das neue Sozialprinzip 
Katolicki uznał i zintegrował zasadę ekorozwoju. Niestety pozostaje jeszcze wiele przestrzeni kościelnej nauki i praxis, w których zasada ta jest nieobecna i nieznana. W sposób szczególny chodzi tu o deficyty w refleksji dotyczącej sieciowości i integracji. Postulowana zasada ekorozwoju stanowi syntezę społeczno-etycznej diagnozy czasu (Zeitdiagnose), i jednocześnie stopień miary dla tworzenia przyszłości we wszystkich płaszczyznach politycznej aktywności. Koncepcja ekorozwoju odkrywa nowe luki w teorii sprawiedliwości. Ona wiąże w sobie centralne pytania przyszłości jako tematy wzajemnie się implikujące. Rozważana koncepcja podkreśla szczególne znaczenie dwóch faktorów: czasowego ${ }^{14}$ i naturalnego we wszystkich społeczno-politycznych problemach (Por. Tamże: s. 478). I w tym miejscu jeszcze raz należy przypomnieć o roli i znaczeniu etyki teologicznej, a szczególnie katolickiej nauki społecznej. Otóż, nie może koncepcja ekorozwoju stać się nad-teorią dla wszystkich problemów, jakie spotykamy we współczesnym świecie. Niewątpliwie daje nam ona jakiś klucz do rozwiązywania tych problemów, próbuje połączyć rzeczywistości społeczne, środowiskowe, ale nie może stać się utopią, która w sposób bezgraniczny decyduje o przyszłości świata. Dlatego potrzeba krytyki ideologicznej ${ }^{15}$.

Vogt wskazuje także na logiczny rdzeń ekorozwoju. Chodzi w tym przypadku o przejście od linearnego do sieciowego myślenia, od kon-

„Nachhaltigkeit” als Antwort auf die ökologische Herausforderungen, w: Handbuch der Wirtschaftsethik, red.: W. Korff i in., Gütersloch 1999, T.1, s. 237-257; H. Wulsdorf, T. Schaertl, Nachhaltigkeit. Vom Schlagwort zum Prinzip, w: Ethica 12 (2004) s. $137-162$.

14 Vogt odnosi się w tym miejscu do Veitha, który pisze o innowacyjnym aspekcie temporalnym w dyskursie dotyczącym rozwoju zrównoważonego i trwałego: „Der innovative Beitrag des Nachhaltigkeitsdiskurses zur Konzeption von Gerechtigkeit liegt allerdings nicht in spezifisch kirchlichen Zugängen, sondern vor allem im diachronen Aspekt einer justitia temporalis. Der temporale Aspekt ist der innovative Fokus des Nachhaltigkeitsdiskurses“ (Veith, 2006: 174-185).

15 „Der Nachhaltigkeit braucht eine begleitende Ideologiekritik von Seiten der Philosophie, der Theologie, der Soziologie sowie der Kultur- und Geschchtswissenschaften. Seine Besonderheit liegt darin, dass er als Querschnittsdiskurs die unterschiedlichen Perspektiven zu bünden vermag, nicht darin, dass er ihnen übergeordnet wäre“ (Vogt: 478). 
centracji na pojedynczych obiektach i jego linearnych łańcuchach przyczyn do kompleksowych i siecio-podobnych całości (Tamże, s. 478-479). Samo ujęcie teologii stworzenia, $\mathrm{z}$ uwzględnieniem teorii kwantowej i teorii chaosu, daje nowe implikacje dla działania proekologicznego (Por. Tamże: 306-322).

\section{Bibliografia}

Baumgarten Ch., 2005, Umweltethik - Umwelhandeln. Ein Beitrag zur Lösung des Motivationsproblems, Paderborn.

Benedykt XVI, 2009, Caritas in veritate, O integralnym rozwoju ludzkim, Pol. Wyd.: AA s.c., Kraków.

Münk H.J., 1998, Nachhaltige Entwicklung und Soziallehre, StZ 216 (1998) z.4, s. 231245.

Münk H.J., 1990, Retinität als neues Sozialprinzip, w: Festschrift für Bischof Dr. Josef Homeyer, Schreer W, Steins G., (red.), „Auf neue Art Kirche sein. WirklichkeitenHerausforderungen-Wandlungen“. München, s. 540-549.

Sachs W., 2003, Nach uns die Zukunft. Der globale Konflikt um Gerechtigkeit und Ökologie, Frankfurt a.M.

Veith W., 2006, Intergenerationelle Gerechtigkeit. Ein Beitrag zur sozialethischen Theoriebildung, Stuttgart.

Vogt M., 1999, Das neue Sozialprinzip „Nachhaltigkeit” als Antwort auf die ökologische Herausforderungen, w: Korff W. i in. (red.), „Handbuch der Wirtschaftsethik“, Gütersloch, T.1, s. 237-257.

Vogt M., 2009, Prinzip Nachhaltigkeit. Ein Entwurf aus theologisch-ethischer Perspekti$v e$, Wyd.: oekom, München.

H. Wulsdorf, T. Schaertl, 2004, Nachhaltigkeit. Vom Schlagwort zum Prinzip, Ethica 12 (2004), s. 137-162.

\section{ZUSAMENFASSUNG}

\section{Marcus Vogt's versuch der integrierung der prinzipien nachaltigkeit in der Katolische Soziallehre}

Im Aritkel stellen wir der Versuch Prof. Marcus Vogt der Integrierung der Prinzipien Nachaltigkeit in der katholische Soziallehre dar. Als Ausgangspunkt dient uns vereoffentlichte Habilitationsschrift "Prinzip Nachaltigkeit. Ein Entwurf aus theologisch-ethischer Perspek- 
tive" (Muenchen, 2009). Im ersten Punkt stellen wir ganz allgemein das Konzept der Nachhaltigkeit dar. Im zweiten Teil beschreiben wir die originäle Aufgabe der Kirche im Bereich der Konzipierung der sittlichen Normen unter dem Licht des Glaubens. Im dritten Teil suchen wir mit M. Vogt der Antwort auf die Frage: welche Ethik für nachhaltige Entwicklung. Das Konzept der Nachhaltikeit gilt als Leitbild und unverbindliche Leerform, was bringt die Problem emit sich. Die Aufzählung der Problemen im Punkt vier. Der Punkt vier bringt uns die Antwort auf die Frage, die der Titel des Aufsatzes enthält. Der Meinung N. Vogt nach gibt es Möglichkeit der Integrierung des Prinzips Nachhaltigkeit in der katholische Soziallehre. Dank dieser Integrierung öffnen sich auch für die traditionellen Prinzipien der Personalität, Solidarität und Subsidiarität neue Interpretationsaspekte. 